\title{
Atık Yumurta Kabuğu Katkısının Polyester Kompozit Malzeme Üretimine Etkisi
}

\section{Influence of the Waste Eggshell Addition to Production of the Polyester Composite Material}

\author{
Alev Akpınar Borazan ${ }^{1 *}$, Duygu Kuru², Süleyman Sert ${ }^{3}$
}

\author{
Geliş / Received: 25/06/2019
}

Revize / Revised: 23/08/2019

Kabul / Accepted: 28/08/2019

$\ddot{O}$ zet- Bu çalışmada, atık yumurta kabuğundan hazırlanan katkı ile güçlendirilmiş polyester esaslı kompozit malzeme üretilmiştir. Atık yumurta kabukları yerel bir yemek firmasından alınarak temizlenip, kurutulup öğütülmüş ve ardından elenmiştir. Polyestere farklı oranlarda yumurta kabuğu takviye oranı $(12,5 ; 10,0 ; 7,5 ;$ 5,$0 ; 2,5 \%$ hacimce), partikül boyutu $(\theta>0,500 \mu, 0,500 \mu>\theta>0,250 \mu, 0,250 \mu>\theta>0,125 \mu, 0,125 \mu>\theta>0,090 \mu, 0,090 \mu>\theta)$ ve kalsinasyon sıcaklığı $\left(800{ }^{\circ} \mathrm{C}, 900{ }^{\circ} \mathrm{C}\right.$ ve $\left.1000{ }^{\circ} \mathrm{C}\right)$ uygulamalarının etkisi denenmiştir. Bu amaçla kompozit malzemeye üç nokta eğme, sertlik, su emme, gözeneklilik gibi testler uygulanmış ve son olarak SEM uygulamasıyla kompozitlere mikro yapı analizi yapılmıştır. XRD analizi ile kalsinasyondan sonra yumurta kabuğunun kristal yapısındaki değişimler ortaya konmuştur. Partikül boyutu $\theta<90 \mu$ 'dan küçük ve kompozit karışımında \%12,5 oranında yumurta kabuğu katılması en iyi fiziksel ve mekanik özellikleri vermiştir. Kalsinasyon uygulamasında kalsinasyon sıcaklık artışı birçok fiziksel ve mekanik özelliği olumsuz etkilemiştir. Elde edilen test sonuçlarına göre yumurta kabuğunun kompozit malzeme üretiminde kullanımının uygun olacağı belirlenmiştir.

Anahtar Kelimeler- Atık Yumurta Kabuğu, Polyester Kompozit, Kalsinasyon, Geri Dönüşüm

$A$ bstract- In this study, polyester based composite material reinforced with additive prepared from waste eggshell was produced. The waste eggshells were supplied from a local catering company, cleaned, dried and ground and then sieved. Egg shell reinforcement ratio $(12.5 ; 10.0 ; 7.5 ; 5.0 ; 2.5 \%$ by volume), particle size $(\theta>0.500 \mu, 0.500 \mu>\theta>0.250 \mu, 0.250 \mu>\theta>0.125 \mu, 0.125 \mu>\theta>0.090 \mu, 0.090 \mu>\theta)$ and calcination temperature $\left(800{ }^{\circ} \mathrm{C}, 900\right.$ ${ }^{\circ} \mathrm{C}$ and $1000{ }^{\circ} \mathrm{C}$ ) were tested. For this purpose, three-point bending, hardness, water absorption, porosity tests were applied to the composite material and finally microstructure analysis was carried out with SEM application. XRD analysis revealed changes in the crystal structure of the eggshell after calcination. The addition of $12.5 \%$ eggshell in the composite mixture with particle size less than $90 \mu$ gave the best physical and mechanical properties. Increasing of calcination temperature has adversely affected many physical and mechanical properties. According to the test results, it was determined that the eggshell would be suitable for the production of composite materials.

Keywords- Waste Eggshell, Polyester Composite, Calcination, Recycles

\footnotetext{
1,*Sorumlu yazar iletişim: alev.akpinar@bilecik.edu.tr (https://orcid.org/0000-0002-3815-2101) Kimya Mühendisliği Bölümü, Bilecik Şeyh Edebali Üniversitesi, Gülümbe Kampüsü, BİLECIKK 2İletişim: duygu.gokdai@bilecik.edu.tr_https://orcid.org/0000-0002-9727-5785 Kimya Mühendisliği Bölümü, Bilecik Şeyh Edebali Üniversitesi, Gülümbe Kampüsü, BİLECIK 3̇letişim: suleyman.sert1995@gmail.com_https://orcid.org/0000-0002-8653-6572) Kimya Mühendisliği Bölümü, Bilecik Şeyh Edebali Üniversitesi, Gülümbe Kampüsü, BİLECIK
} 


\section{GİRIŞ}

Gıda Sanayinde ve/veya tarımsal üretim sonrasında açığa çıkan gıda atıklarının bir kısmı imha edilirken bir kısmı da farklı teknolojiler kullanılarak ekonomik değeri daha düşük hayvan yemi, gübre vb. ürünlerin üretiminde kullanılmaktadır. Günümüzde gıdaların işlenmesi sırasında ortaya çıkan gıda atıklarının yeniden değerlendirilmesine, çevre kirliliğinin önlenmesine katkı sağlayabilecek ve ülke ekonomisini güçlendirecek biçimde katma değer kazandırılmış yeni ürünlerin veya ikame etmesi planlanan ürünlerle rekabet edebilir yönde yeni ürünlerin imal edilmesi çalışmaları yapılmaktadır.

Türkiye İstatistik Kurumunun 2002-2018 yılları arasındaki kanatlı hayvan verilerine göre yumurta üretimi her yıl artarak 2018 yılında 20 milyon adete ulaşmıştır. Bahsi geçen 16 yıllık sürekli artış süreci, artan nüfus oranına bağlı olarak ortaya çıkan arz ve talepteki artışın önemli bir göstergesidir. Yapılan araştırmalara göre tavuk yumurtası kabuğu, çevre kirliliğine yol açan tehlikeli atıklardan biri olsa da özellikle yumurta ve yumurta ürünleri endüstrisinin iyi gelişmiş olduğu ülkelerde listelenmiş bir tarımsal yan ürün olarak belirlenmiştir. Tavuk yumurtası kabukları, restoranlarda, gıda endüstrilerinde (özellikle hazır yemek üretim şirketlerinde), evlerde atık ürünler olarak açığa çıkmaktadırlar. Yumurta kabuğu gibi biyolojik atıkların kontrolsüz olarak çevreye çöp olarak atılması kötü koku yanında çok daha önemli mikrobiyal gelişme ve kirliliklere yol açmakta bu da insan sağlığı açısından risk oluşturmaktadır. Oysa yumurta kabuğu sahip olduğu bileşim ögelerinden özellikle kalsiyum karbonat açısından oldukça zengindir. Yumurta kabuğu, kalsit formunda ağırlıkça \%95 kalsiyum karbonat ve ağırlıkça \%5 organik materyal içeren bir biyo-materyaldir. Bu özellikleri yumurta kabuğunun uygun dönüşüm işlemleri ve farklı karışım reçeteleriyle yeni malzemelerin üretiminde kullanılabilecek, araştırılmaya değer nitelikte olduğunu göstermektedir [1]. Yumurta kabuğu atıkları katma değer kazandırılarak yeni ürünlere dönüştürülmezse çöp olarak atılacaktır ve çevreye kirlilik yaratacaklardır.

Teknolojik ilerlemeler ve yapısal malzeme türlerinin artması mevcut malzeme özelliklerinin sürekli geliştirilmesini gerektirmektedir. Kompozit malzemelerde bu amaçla geliştirilmiştir. Kompozit malzemelerde, üretilmesi planlanan materyalin var olan eksikliklerinin giderilmesi ve özelliklerin daha da iyileştirilmesi istenmektedir [2,3].

Polimer bazlı üretim yapan üreticiler, çevreye duyarlı ürünler üretmek ve sunmak üzere kullanılan kimyasal madde miktarını azaltmak için alternatif yaklaşımlar araştırmaktadır. Bu kapsamda, bazı araştırmalar katkı maddelerinin bir kısmı yerine; odun, tahıl gibi bir bitki esaslı atık ve talaşların "biyo-esaslı" dolgu maddesi olarak kullanılmasını içermektedir. Bununla birlikte, bitki esaslı dolgu maddeleri işleme sırasında kullanılan yüksek sıcaklıklarda bozulmakta, bu da kötü ürün performansı ve istenmeyen özelliklere yol açmaktadır. Ayrıca, son yıllarda toplumda çevre bilincinin gelişmesiyle ve değişen yasal düzenlemelere göre orman kullanımının azaltılması ve tarımsal atıkların bertaraf edilmesi yönünde baskılar bulunmaktadır.

Yumurta kabuğu ile ilgili literatürde birçok çalışma bulunmaktadır. Toro ve arkadaşları (2007) yaptıkları çalışmada katkı maddesi olarak tavuk yumurtası kabuğu (ES) ve matriks malzemesi olarak polipropilen (PP) kullanarak farklı boyut ve oranlarda kompozitler üretmişlerdir. PP kompozit malzemede dolgu maddesi olarak yumurta kabuğunun farklı oranları ile farklı boyut ve oranlardaki ticari talk ve kalsiyum karbonatı karşılaştırmışlardır. Çekme deneyleri sonucunda young modülünün (E) yumurta kabuğu oranının artması ile iyileştiğini gözlemlemişlerdir. ES/PP kompozitleri daha düşük E değerlerine sahip olmasına rağmen talk dolgusunun ES ile \%75 oranında yer değiştirebileceğini, talk kompozitlerine kıyasla benzer bir sertlik derecesini ve E değerlerini koruduğunu gözlemlemişlerdir. Kırık yüzey üzerinden aldıkları SEM görüntülerinde gelişmiş bir ara yüzey bağı olduğunu belirtmişlerdir. Yumurta kabuğunun geometrik oranının ES/PP kompozitlerinin mekanik özelliklerinde genel olarak artış sağladığını belirlemişlerdir [4]. Shuhadah ve Supri (2009) polietilen/yumurta kabuğu toz kompozitlerinin mekanik özelliklerini, morfolojisini ve su emme üzerine olan etkilerini araştırmışlardır. Bağlayıcı olarak izoftalik asit kullanımının düşük yoğunluklu polietilen (LDPE)/ yumurta kabuğu (ESP) kompozitlerinin çekme mukavemetini, direncini ve su emilimini arttırdığını belirtmişlerdir. LDPE/modifiye edilmiş ESP kompozitlerinin kırılma yüzeylerinde yapılan morfolojik çalışmalar da daha yüksek mukavemete ve daha iyi etkileşime sahip olduğunu göstermiştir [5]. Hassan ve arkadaşları (2012) yaptığı çalışmada polyester/yumurta kabuğu partiküllü kompozit üretmişlerdir. Yaptıkları çalışmada yumurta kabuğu parçacıklarının yüzdesinin artmasıyla orantılı olarak gerilme ve eğilme mukavemetlerinin de arttığını, polyester matrisine yumurta kabuğunu takviyesinin artmasıyla sertliğinin de arttığını, SEM çalışmalarında da karbonize yumurta kabuğu kullanıldığında partiküller arasında daha iyi bir ara yüzey bağı oluştuğunu gözlemlemişlerdir [6]. Bootklad ve Kaewtatip (2013) yaptıkları çalışmada termoplastik nişasta (TPS) ve dolgu maddesi olarak tavuk yumurtası kabuğunu (EP) sıkıştırarak kaplama yöntemi ile hazırlamışlardır. EP'nin TPS özellikleri üzerine etkisini; ticari kalsiyum karbonat (CC), kabuklu su tozu yüzeyindeki organik bileşiği, EP ve TPS matrisi arasında güçlü bir yapışmayla sonuçlanan bir bağlantı maddesi, SEM görüntüleri ile teyit etmişlerdir. 
Biyolojik bozunumu toprağa gömme testi ile belirlemişlerdir. TPS/EP kompozitlerinin TPS/CC kompozitlerinden daha hızlı şekilde bozunduğunu görmüşlerdir. Bunlara ek olarak EP dolgu maddesinin TPS'nin su direncini ve termal stabilitesini geliştirdiğini fark etmişlerdir [7]. Nwanonenyi ve Onyegbula (2013) yaptıkları araştırmalarında düşük yoğunluklu polietilen/yumurta kabuğu polimer kompozit numunelerinde iyileştirilmiş özellik elde etmek için ağırlıkça değişen oranlarda yumurta kabuğu tozu kullanmışlardır. Farklı parçacık boyutlarında dolgu maddesi içeriğinin bir fonksiyonu olarak doğrusal düşük yoğunluklu polietilen/yumurta kabuğu toz kompozitlerinin su emme, yanıcılık ve mekanik özelliklerini test etmişlerdir. Gerilme mukavemeti, kopma uzaması, gerilme modülü, darbe ve eğilme testi gibi parametreleri incelemişlerdir. Sonuçta ise çekme mukavemetinde, uzamada, gerilme modülünde, eğilme mukavemetinde ve eğilme modülünde önemli ölçüde azalma olduğunu gözlemlemişlerdir. Su emme sonuçlarında ise maruz kalma süresine paralel olarak artış olduğunu belirtmişlerdir [8]. Ramesh ve arkadaşları (2014) yaptıkları çalışmada poliamit/yumurta kabuğu kompozitini üretip çekme mukavemeti, darbe mukavemeti, bükülme mukavemeti gibi mekanik testler gerçekleştirmişlerdir. Çekme gerilmesinin, bükülme mukavemetinin, darbe mukavemetinin ve yoğunluğun yumurta kabuğu tozu miktarıyla arttığını tespit etmişlerdir [9]. Senthil ve Raj (2015) çalışmalarında yumurta kabuğu polimer kompozitlerinin mekanik özellikleri ve su emme özelliklerini araştırmışlardır. Polyester reçinelerin kalsiyum karbonat ve yumurta kabuğu tozuyla iyi bir kompozit yapısı oluşturduğunu gözlemlemişlerdir. İki farklı yumurta tozu ağırlık oranında elde edilen (\%15-\%20) polimer kompozitlerin çekme dayanımı, eğilme direnci ve SEM analizleri yapılmıştır. SEM görüntülerinde bilyalı öğütme işlemi sonucunda mikrometre boyutunda parçacıklara ve pürüzsüz yüzeyli pıhtılaşmış kaba tanelere rastlamışlardır. Kompozitlerin kırılma noktasında uzama artışı gözlemlenmiştir. Yumurta kabuğu tozunun plastik endüstrisinde yenilenebilir bir kaynak olduğunu belirtmişlerdir. Kompozitlerde yumurta kabuğunun kullanılmasının maliyeti azalttığını ve çevre dostu kompozitler üretildiğini belirtmişlerdir [10]. Yapılan çalışmada hazır yemek üretimi yapan bir yemek firmasından temin edilen atık yumurta kabukları, düzenli kullanım için hazırlanmış (yıkama-kurutmaögütme-eleme) ve polimer kompozitlerde ucuzlatıcı dolgu maddesi olarak kullanımı sağlanmıştır. Bunun yanı sıra atık yumurta kabuğu kullanımı, düşük yoğunlukta, daha hafif ve mekanik özellikleri iyileştirilmiş polyester kompozit malzemenin üretilmesine imkan vermiştir.

\section{MALZEMELER}

Kompozit üretimi için matris olarak polyester reçine (Polipol 383-G, Poliya Composite Resins and Polymers Inc., yoğunluğu, 1,076 $\pm 0,05 \mathrm{gr} / \mathrm{cm}^{3}$ ), dolgu maddesi olarak yumurta kabuğu (Bilecik Subaşı Et ve Et Mam. Gıda SAN. TİC. LTD. ŞTİ.), hızlandırıcı olarak kobalt (\%2'lik çözelti) ve sertleştirici olarak ise metil etil keton peroksit (MEKP, Butanox ${ }^{\mathrm{TM}}$ M-60, AkzoNobel Products) kullanılmıştır. Kalıpların kolay ayrılması için kalıp yağlayıcı (Polivaks, MASKIM.0007) kullanılmıştır.

Bilecik Subaşı Et ve Et Mam. Gıda SAN. TİC. LTD. ŞTİ. firmasından toplanan yumurta kabukları yıkanıp oda sıcaklığında kurutmaya alınmıştır. Temizlenip kurutulan yumurta kabukları çekiçli değirmen öğütücüde (Brook Cromption Series 2000, ENGLAND) öğütülmüştür. Öğütülen yumurta kabukları elenip farklı boyutlara ayrılmıştır $(\theta>0.500,0.500>\theta>0.250,0.250>\theta>0.125,0.125>\theta>0.090,0.090>\theta)$. Çalışmada karışımın homojen dağılımının sağlanması nedeniyle partikül boyutu daha büyük olan yumurta kabukları $(\theta>0.500$, $0.500>\theta>0.250)$ kalsine edilmek üzere tüp firında " $210{ }^{\circ} \mathrm{C}-1 \mathrm{sa}, 450{ }^{\circ} \mathrm{C}-1 \mathrm{sa}$., $800{ }^{\circ} \mathrm{C} / 900{ }^{\circ} \mathrm{C} / 1000{ }^{\circ} \mathrm{C}-3$ sa." şartlarında 1 sıl işleme maruz bırakılmıştır. Kalsine yumurta kabukları tekrar bu kez bilyalı değirmende $3 \mathrm{~cm}$ çaplı 4 adet toplam 53 gr ağırlığında bilya kullanılarak $(100 \mathrm{~mL}$ iç hazneli, Fritsch, Vibrating Cup Mill Pulverisette 9 , GERMANY) 10' ar dakika öğütülmüş ve eleme yapılmıştır; kalsine yumurta kabuğu boyutunun $\theta \leq 0.090$ aralığında olduğu belirlenmiştir.

\section{YÖNTEM}

\section{A. Yumurta Kabuğu/Polyester Kompozit Üretimi}

Ön hazırlığ̣ tamamlanmış yumurta kabuğu ve kalsine yumurta kabuğu kullanıldığı ve analiz edilmek üzere hazırlanan farklı reçeteler için uygulanan kompozit malzeme üretim işlemleri Şekil 1'de sunulmuştur. 


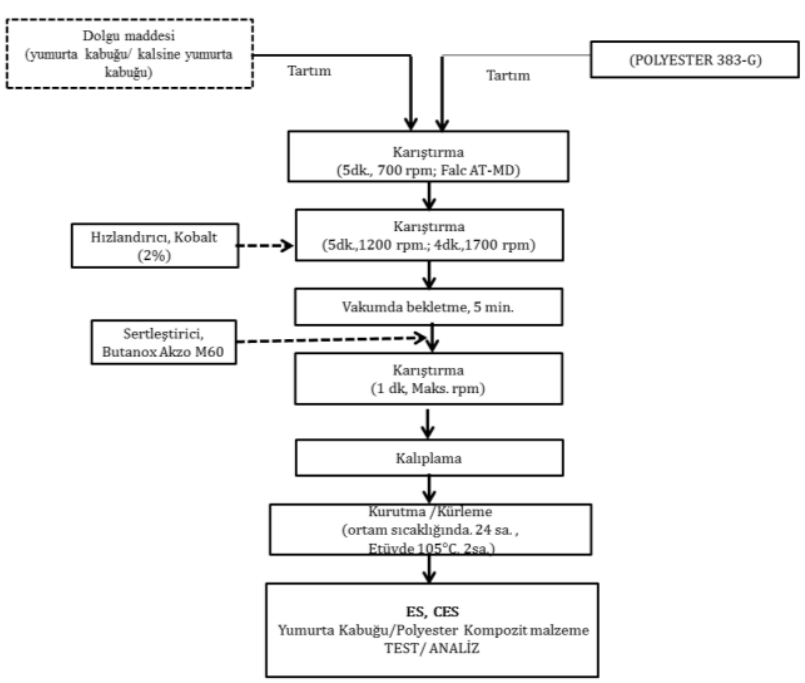

Şekil 1. Yumurta kabuğu/polyester kompozit üretim akım şeması

Hazırlanan dolgu malzemeleri ve polyester belirlenen oranlarda tartıldı. Karıştırıcı (Falc, Rod Stirrer AT-MD 10 ITALY) kullanılarak sırasıyla 700, 1200, ve 1700 rpm'lik hızlarda yaklaşık 5'er dakika karıştıııldı. Homojen bir karışım sağlandıktan sonra belirlenen miktarlarda kobalt ve butanox eklendi. Kobalt ilavesinden sonra kompozit yapısında meydana gelebilecek hava kabarcıklarını önlemek amacıyla karışım 5 dakika boyunca vakumda bekletildi. Kalıplara dökülen karışım, oda sıcaklığında 1 gün bekletilip kalıptan çıkarıldı. 2sa sonra etüvde (Binder, Germany) $105{ }^{\circ} \mathrm{C}$ 'de kürleşmesi sağlandı. Hazırlanan kompozit malzeme kalıba dökümü gerçekleşmeden önce kalıp, kalıp ayırıcı (Polivax) ile yağlandıktan sonra etüvde (Binder, Germany) $60{ }^{\circ} \mathrm{C}^{\prime} \mathrm{de} 10$ dakika kuruması sağlanmış olup kalıp döküme hazır hale getirilmiştir.

Polyester kompozit malzemenin üretiminde atık olarak kullanılan yumurta kabuğu tozunun farklı oranları kullanılarak araştırmaya en uygun reçeteler araştırılmıştır. Ayrıca üretimde en iyi mekanik özellikler gösteren reçetede $(\% 12,5)$ farklı sıcaklıklarda kalsine edilmiş yumurta tozu diğeri yerine ilave edilerek denemeler tekrar edilmiştir. Hazırlanmış reçete ve tanımları Tablo 1'de verilmiştir.

Tablo 1. Kompozit oluşumunda kullanılan döküm reçetesi

\begin{tabular}{|c|c|c|c|c|c|c|}
\hline \multirow{2}{*}{ Reçete Tanımı } & \multirow{2}{*}{ Kod } & \multicolumn{5}{|c|}{$\operatorname{Hacim}\left(\mathrm{cm}^{3}\right)$} \\
\hline & & $\overline{12,5}$ & 10 & $\overline{7,5}$ & 5 & 2,5 \\
\hline Yumurta kabuğu/polyester kompozit & ES & $31,3 \mathrm{~g}$ & $25 \mathrm{~g}$ & $18,8 \mathrm{~g}$ & $12,5 \mathrm{~g}$ & $6,3 \mathrm{~g}$ \\
\hline Kalsine yumurta kabuğu/polyester kompozit & CES & $29,8 \mathrm{~g}$ & -- & -- & -- & -- \\
\hline
\end{tabular}

Karışımlar hep aynı hacimdeki kalıba dökülmüştür bu nedenle kalıp hacmi esas alınarak toplam hacimde yumurta kabuğunun hacmine bağlı olarak ağırlıkları değiştirilmiştir. Hepsinde 60 gr polyestere göre farklı hacimlere $(12,5 ; 10 ; 7,5 ; 5 ; 2,5)$ uygun olacak şekilde yumurta kabuğu ağırlığ 1 hesaplanmıştır. Hesaplamada yumurta kabuklarının yoğunlukları gaz piknometresi (AccuPyc II 1340 V1.05, Micromeritics) ile bulunmuş buradan ilgili hacim için kaç gram alınacakları hesaplanmıştır: kalsine yumurta kabuğu: $2.3817 \mathrm{gr} / \mathrm{cm}^{3}$, yumurta kabuğu: $2.5020 \mathrm{gr} / \mathrm{cm}^{3}$.

\section{B. Analiz Yöntemleri}

Dökümü yapılan kompozitlerin mukavemet değerlerini ölçmek için 3 nokta eğme cihazı (Shimadzu, AG-IC) ile ölçüm yapılmıştır. Numunelere uygulanan test sonuçlarının ortalama değerleri alınmıştır. Testlerde cihaz $2 \mathrm{~mm} / \mathrm{dk}$ 'lık hıza ayarlanmıştır. Numuneler kırıldıktan sonra kırık yüzey yakınında genişlik (W) ve kalınlık (D) değerleri kumpas ile ölçülmüştür.

Mukavemet $(\sigma)$ değerleri ve Elastik modül (E) verileri 3-nokta eğme testi ile aşağıdaki eşitlik kullanılarak belirlenmiştir: 


$$
\begin{gathered}
\sigma_{f}=(3 P L) /\left(2 b d^{2}\right) \\
E_{f}=\left(L^{3} m\right) /\left(4 b d^{3}\right)
\end{gathered}
$$

\section{Burada}

P: Kırılma yükü $(\mathrm{N})$; L: Destekler arası mesafe $(\mathrm{m})$; b: Numunenin genişliği (m); d: Numunenin kalınlığı (m); m: Gerilim-deformasyon $(\sigma-\varepsilon)$ eğrisinin eğimi $(\mathrm{N} / \mathrm{m})$

Örnek numuneler sertlik ölçme makinesine yerleştirilip kompozit malzemelerin 5 farklı bölgesinde sertlik ölçümü gerçekleştirilmiştir (SLX-D Shore-D Durometre). Hesaplamalarda elde edilen bu 5 değerin ortalaması kullanılmıştır.

Numunelerin yoğunluğu Archimed'in su ile yer değiştirme prensibine göre ölçülmüştür. Bu prensibe göre bir maddenin sıvı içindeki ağırlığı, o maddenin kuru ağırlığı ile batmaya karşı gösterdiği direnç kuvvetinin farkına eşittir. 2000 ml'lik beherin dibine seramik taşlar yerleştirilmiştir. Üzerine saf su koyulup ağzı alüminyum folyo ile kapatılmıştır. Folyo üzerinde küçük delikler açılmıştır. Manyetik 1sıtıcıda (Ika, C-MAG HS7, GERMANY) kaynayana kadar bekletilmiştir. Daha sonrasında önceden seçilen; kalınlıkları, genişlikleri ve ağırlıkları ölçülen numuneler saf su içerisine yerleştirilmiştir. 2 saat boyunca kaynatıldıktan sonra 1sıtıcı kapatılmıştır. Numuneler 24 saat saf suda bekletilmiştir. 24 saat sonra su içerisinden alınan numuneler havlu peçete ile hafifçe kurulanıp kalınlıkları, genişlikleri ve ağırlıkları tekrar ölçülmüştür. Daha sonrasında askıda ve havada ağırlıkları alınıp kompozitlerin su emme, açık gözeneklilik yüzdesi, toplam gözeneklilik yüzdesi, teorik yoğunluk ve kütle yığın yoğunluğu hesapları şu şekilde yapılmıştır;

$$
\begin{aligned}
& \text { Su Emme }(\%)=[(\text { Yaş Ağırlık- Kuru Ağırlık }) /(\text { Kuru Ağırlık })]^{* 100} \\
& \text { Kütle yı̆̆ın yoğunluk }=\left[\mathrm{W}_{1} /\left(\mathrm{W}_{2}-\mathrm{W}_{3}\right)\right] \times \rho_{\mathrm{su}} \\
& \% \text { Açık gözeneklilik= }\left[\left(\mathrm{W}_{3}-\mathrm{W}_{1} /\left(\mathrm{W}_{3}-\mathrm{W}_{2}\right)\right] \times 100\right. \\
& \% T Y=[(\text { B.Y. }) /(\mathrm{T} . \mathrm{Y} .)] \mathrm{x} 100 \\
& \% \text { Toplam Gözeneklilik }=100-\% \mathrm{TY}
\end{aligned}
$$

$\mathrm{TY}=$ Teorik yoğunluk, $W_{l}=$ Kuru ağırlık, $W_{2}=$ Askıda ağırlık, $W_{3}=$ Sıvı sızdırılmış haldeki ağırlıkları

Kompozit numunelerin yüzey ve kesit morfolojisi, kompozitlerin kırık yüzeyinden Taramalı Elektron Mikroskobu (SEM., Zeiss Supra 40VP) kullanılarak incelenmiştir. Numuneler platin ile kaplandıktan sonra farklı büyütme oranlarında görüntüleri alınmıştır. Kalsinasyondan sonra yumurta kabuğunun kristal yapısındaki değişim X-Ray Difraktometresi (XRD, PANALYTICAL, EMPYREAN) cihazı ile analiz edilmiştir. Analiz 5-90 2 Theta (derece) aralığında 0,05 adım aralığı kullanılarak gerçekleştirilmiştir.

\section{BULGULAR VE TARTIŞMA}

\section{A. Mekanik Dayanım Sonuçları}

Yapılan testler sonucunda yumurta kabuğu tozunun artan hacim oranlarıyla eğilme dayanımında artış olduğu gözlemlenmiştir. En yüksek eğilme dayanımına 12,5 hacim oranında ve $\theta<0,090$ boyutundaki yumurta kabuğu takviyeli kompozit malzemenin sahip olduğu tespit edilmiştir (Şekil 2a). Kalsiyum karbonat $\left(\mathrm{CaCO}_{3}\right)$ miktarının hacimce oranın artmasıyla kompozit malzemeler daha dayanıklı bir hal almıştır. $\mathrm{CaCO}_{3}$ yapısal olarak kompozit malzemelere mukavemet kazandıran bir bileşiktir [11]. Dayanıklılığı ve mukavemeti arttırdığı için de kompozit malzemelerin eğilme dayanımı artan hacim oranlarıyla artış göstermiştir. 


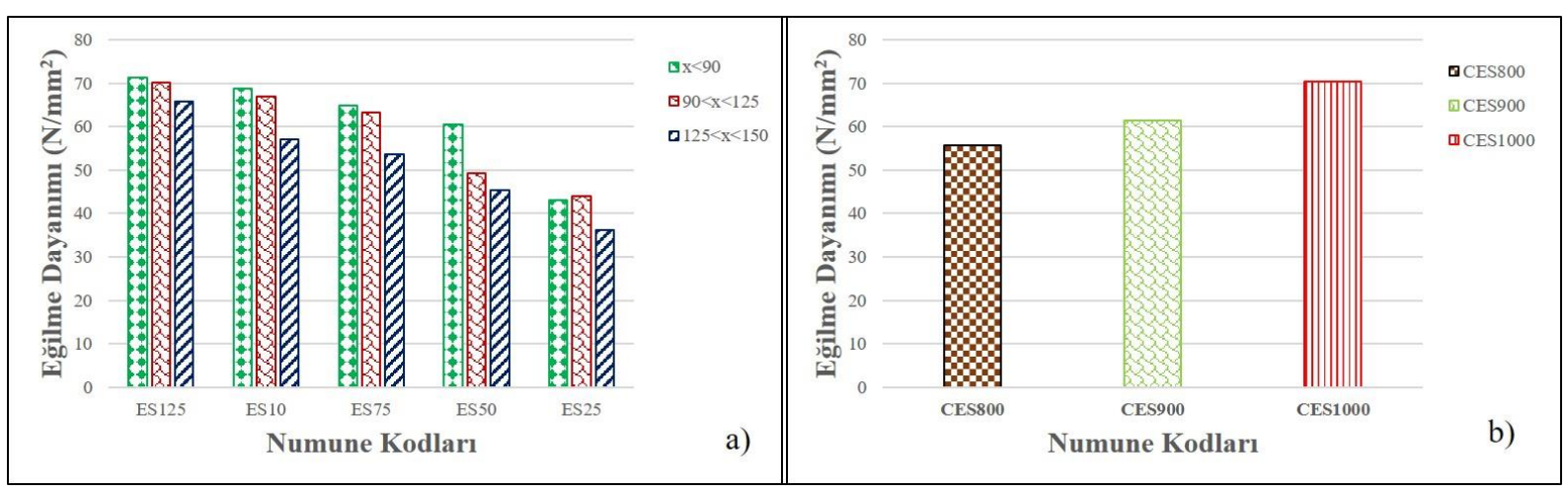

Şekil 2. Eğilme dayanımına a) Yumurta kabuğu b) Kalsine yumurta kabuğu ilavesinin etkisi

En düşük parçacık boyutu esas alındığında hacimce \%2,5 oranında yumurta kabuğu kullanılan kompozitin eğilme dayanımı $43 \mathrm{~N} / \mathrm{mm}^{2}$ iken \%12,5 yumurta kabuğu takviyesinde bu değer 71,3 N/mm² ye yükselmiştir. Yaklaşı \% 40 oranında mekanik dayanımda iyileşme söz konusu olmuştur. Kalsine işleminden geçirilmiş yumurta kabuğu tozlarında ise sıcaklığın artışıyla eğilme dayanımı artmıştır ve eğilme dayanımı en yüksek olan kompozit malzemenin $70 \mathrm{~N} / \mathrm{mm}^{2}$ değeri ile $1000{ }^{\circ} \mathrm{C}$ 'de kalsine edilen kompozit malzeme olduğu tespit edilmiştir (Şekil 2b). Zaman ve arkadaşları yapmış oldukları çalışmada $\mathrm{CaCO}_{3}$ 'ün kinetik davranış diyagramına göre, $1100{ }^{\circ} \mathrm{C}$ 'de kalsine edilen yumurta kabuklarının daha düşük sıcaklıklarda kalsine edilenden daha fazla reaktivite gösterdiklerini belirtmişlerdir. Ayrıca düşük sıcaklığın $\left(<1100{ }^{\circ} \mathrm{C}\right)$ kalsinasyonun, kısmi veya eksik ayrışmaya neden olabileceğini belirtmişlerdir. $1100{ }^{\circ} \mathrm{C}$ 'nin üzerindeki işlem ise partiküllerin tane büyümesi ve yoğunlaşma süreci ile reaktivitesini düşürebilmektedir. Yumurta kabuğunun kalsinasyonu sirasında meydana gelen reaksiyonlar aşağıda tanımlanmıştır.

$$
\begin{aligned}
& \mathrm{CaCO}_{3} \longrightarrow \mathrm{CaO}+\mathrm{CO}_{2} \\
& \mathrm{CaO}+\mathrm{H}_{2} \mathrm{O} \longrightarrow \mathrm{Ca}(\mathrm{OH})_{2}
\end{aligned}
$$

Kalsinasyon sıcaklığg ile $\mathrm{Ca}(\mathrm{OH})_{2}$ oluşumunda bir artış eğiliminin tespit edildiğine ve sonuç olarak $1100{ }^{\circ} \mathrm{C}$ 'de kalsinasyonun en yüksek $\mathrm{Ca}(\mathrm{OH})_{2}$ yüzdesini $(\% 79,7)$ ürettiği belirtilmiştir. Literatürdeki reaksiyon mekanizması değerlendirildiğinde eğilme dayanımı grafiklerinde (Şekil 2) görüldüğü üzere kalsinasyon sıcaklığı arttıkça yumurta kabuğunun polimer içerisindeki reaktivitesi artmıştır ve daha güçlü bir ara yüzey bağlanması sağlanmıştır. Bunun sonucunda da daha iyi mekanik özellik göstermesine neden olmuştur [12].

Ramesh ve arkadaşları (2014) yaptıkları çalışmada da yumurta kabuğunun artan miktarıyla çekme gerilmesinin, bükülme mukavemetinin, darbe mukavemetinin ve yoğunluğunun arttığını gözlemlemişlerdir [9].

Kompozit malzemelerin elastikiyet modülleri incelendiğinde çok fazla bir değişim olmadiğ gözlemlenmektedir. Burada yumurta kabuğunun artan hacim oranlarıyla elastikiyet modülünün azalmas1 beklenmiştir. Literatürde yapılan araştırmalarda Gaber ve arkadaşlarının 2012 yılında yaptıkları araştırmada dolgu maddesinin artan oranlarıyla çekme mukavemeti ve gerilme modülünde iyileşme gösterdiğini gözlemlemişlerdir [13].
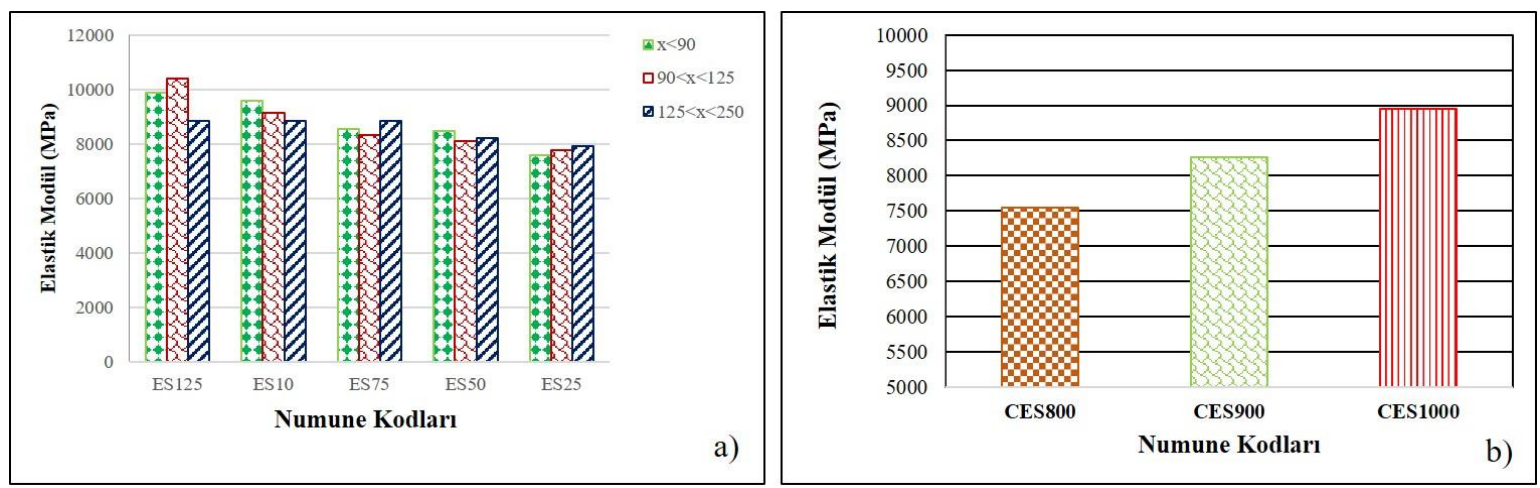

Şekil 3. Elastik modül a) Yumurta kabuğu, b) Kalsine yumurta kabuğu ilavesinin etkisi 
Şekil 3 incelendiğinde yumurta kabuğu tozunun artan hacim oranlarıyla elastik modülünde artış olduğu gözlemlenmiştir. En yüksek elastik modülün yaklaşık $9000 \mathrm{MPa}$ değeri ile, 12,5 hacim oranında ve $\theta<0,090$ boyutundaki yumurta kabuğu tozu takviyeli kompozit malzemenin sahip olduğu tespit edilmiştir (Şekil 3a).

Kalsine işleminden geçirilmiş yumurta kabuğu tozlarında ise sıcaklığın artışıyla elastik modülü artmıştır ve elastik modülü ile en yüksek olan kompozit malzemenin $1000{ }^{\circ} \mathrm{C}$ 'de kalsine edilen kompozit malzeme olduğu tespit edilmiştir (9000 MPa, Şekil 3b).

\section{B. Sertlik Sonuçları}

Yumurta kabuğu tozunun artan hacim oranlarıyla sertliğinde artış olduğu gözlemlenmiştir. Sertlik değerleri 83,5-86,5 değerleri arasında değişim göstermiştir. Düşük parçacık boyutlu kompozitlerin sertlik değerleri orta ve yüksek boyuttaki yumurta kabukları ile elde edilmiş kompozitlerin sertlik değerlerinden fark edilir ölçüde daha yüksektir. $\mathrm{CaCO}_{3}$ kullanılan yapıya sertlik ve mukavemet kattığı için artan hacim oranlarıyla sertliğin artmasının sebebi $\mathrm{CaCO}_{3}$ 'ün bulunma yüzdesinin artmasıdır (Şekil 4a) [11]. Kalsine işleminden geçirilmiş yumurta kabuğu tozlarında ise sıcaklığın artışılla sertlik azalmıştır ve sertliği en yüksek olan kompozit malzemenin 86,2 Shore D değeri ile $800{ }^{\circ} \mathrm{C}$ 'de kalsine edilen kompozit malzeme olduğu tespit edilmiştir (Şekil 4b). Bunun sebebi olarak düşük kalsinasyon sıcaklıklarında kalsinasyon reaksiyonlarının tamamlanmamasının bir sonucu olarak morfolojik yapıda meydana gelen değişiklikler olarak düşünülmüştür. Bununla paralel olarak düşük sıcaklıklarda ağırlık kaybı daha az olduğundan sertlik değeri düşük sicaklıklarda daha yüksek bulunmuştur [12]. Hassan ve arkadaşlarının (2012) yaptığı çalışmada yumurta kabuğu parçacıklarının yüzdesinin artmasıyla orantılı olarak gerilme ve eğilme mukavemetlerinin de arttığını, polyester matrisine yumurta kabuğunu takviyesinin artmasıyla sertliğinin de arttığını, SEM çalışmalarında da karbonlaştırılmış yumurta kabuğu kullanıldığında polyester matrisli partiküller arasında daha iyi bir ara yüzey bağı ortaya çıktığını gözlemlemişlerdir [6].
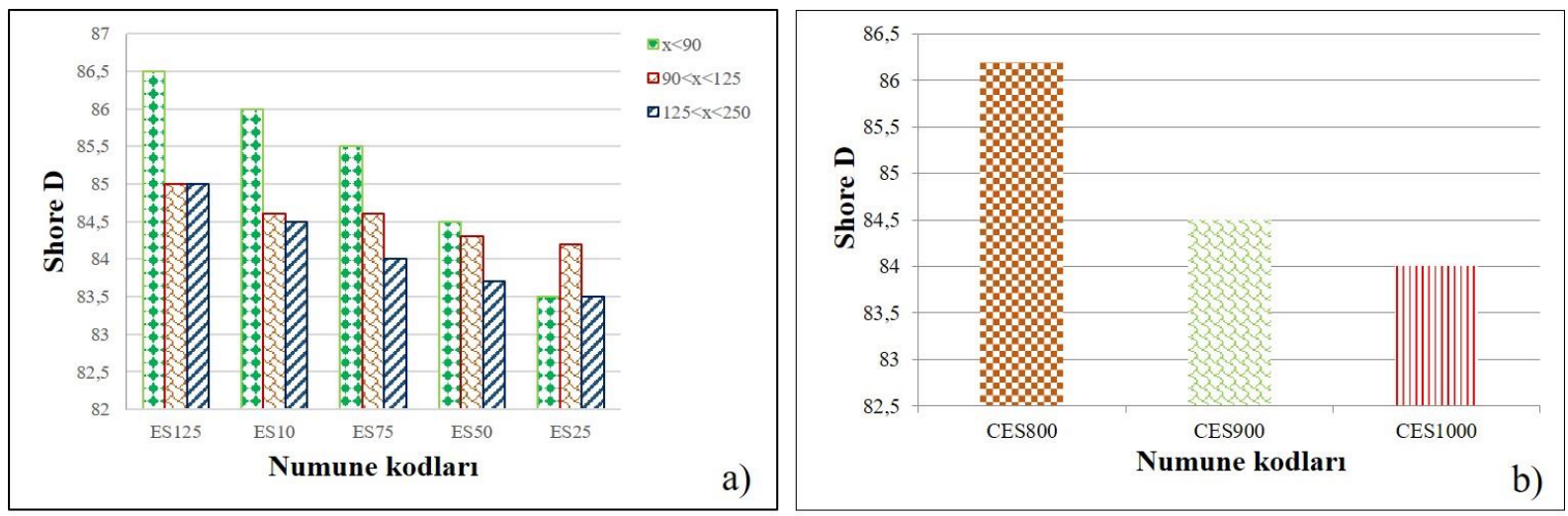

Şekil 4. Kompozit malzemede sertliğe a) Yumurta kabuğu, b) Kalsine yumurta kabuğu ilavesinin etkisi

\section{Fiziksel Analiz Sonuçları}

Kompozitlerde parçacık boyutunun $90 \mu$ 'dan küçük olması mekanik testlerde daha iyi sonuçlar vermiştir. Bu durumun esas nedeni parçacık boyutu azaldığında yumurta kabuğunun kristalliği artış göstermiştir ve polimer matriksi ile daha iyi etkileşime girmesine neden olmuştur [14]. Aynı durum fiziksel analizlerde de görülmüş ve bu nedenle sadece bu boyuta ait sonuçlar sunulmuştur. Yapılan testler sonucunda yumurta kabuğu tozunun artan oranlarıyla kütle yığın yoğunluğunda ve \% şişme kalınlıklarında artış gözlemlenirken \% açı gözenekliliklerinde ve \% su emmelerinde azalma tespit edilmiştir. Kullanılan yumurta kabuğu miktarının \%2,5'dan \%12,5'a arttırılmasıyla birlikte kütle yığın yoğunluğunda \%12,4 oranında bir artış gözlenirken şişme kalınlığında ise \%44,12 oranında bir artış gözlenmiştir. Açı gözeneklilik değerleri yumurta kabuğu miktarı \%2,5'dan \%12,5'a arttıkça \%20,30 oranında azalma gösterirken su emme değerleri de \%20,7 oranında azalma göstermiştir. Kalsine sıcaklığının artmasıyla kütle yığın yoğunluğunda azalma gözlemlenirken \% açık gözenekliliklerinde \% su emmelerinde ve \% şişme kalınlıklarında artış tespit edilmiştir (Tablo 2). Turan (2010) yaptığı çalışmada da $\mathrm{CaCO}_{3}{ }^{\prime}$ ün artan oranlarıyla su emme ve gözenekliliğin azaldığını gözlemlemiştir [15]. 
Tablo 2. $\theta<0,090$ boyutunda döküm yapılan numunelerin fiziksel özellikleri

\begin{tabular}{lllll}
\hline 0 & $\begin{array}{l}\text { Kütle Yı̆̆ın Yoğunluğu } \\
\left(\mathbf{g} / \mathbf{c m}^{\mathbf{3}}\right)\end{array}$ & Açık Gözeneklilik $(\%)$ & $\begin{array}{l}\text { Su Emme } \\
(\%)\end{array}$ & $\begin{array}{l}\text { Şişme Kalınlığı } \\
(\%)\end{array}$ \\
\hline ES125 & 1,412 & 0,785 & 0,642 & 1,106 \\
ES100 & 1,391 & 0,953 & 0,697 & 0,917 \\
ES75 & 1,344 & 0,966 & 0,740 & 0,861 \\
ES50 & 1,296 & 0,973 & 0,682 \\
ES25 & 1,237 & 0,985 & 0,810 & 0,618 \\
CES800 & 1,379 & 1,589 & 1,104 & 0,125 \\
CES900 & 1,357 & 1,663 & 1,225 & 0,271 \\
\hline
\end{tabular}

\section{XRD Analiz Sonuçları}

Şekil 5 kalsine edilmiş ve edilmemiş yumurta kabuklarının XRD spektrumunu içermektedir. Kalsine edilmiş ve edilmemiş yumurta kabuklarının spektrumları incelendiğinde her iki durumda da yapıda görülen fazlar yumurtadaki ana bileşen olan kalsiyum karbonata aittir. $1000{ }^{\circ} \mathrm{C}$ kalsinasyon sonrasında $\mathrm{CaCO}_{3}$ 'e ait piklerdeki şiddetlerin belirli oranda azaldığı gözlenmektedir. Bunun temel sebebi $\mathrm{CaCO}_{3}$ 'ün kinetik diyagramına bağlı olarak bu sıcaklıkta kütlesinin önemli bir kısmını kaybetmesi ve reaksiyon sonucunda farklı ürünlere dönüşmesi ile açıklanabilir. Kinetik diyagram verilerine göre 800, 900, 1000 ve $1100{ }^{\circ} \mathrm{C}$ 'de kalsinasyon sonrasında $\% 87,8, \% 77,2, \% 43,3$ ve $\% 5 \mathrm{CaO}$ üretilmektedir [11]. $\mathrm{CaCO}_{3}$ ’ün $\mathrm{CaO}^{\prime}$ ya dönüşmesi sırasında $\mathrm{CaCO}_{3}$ 'ün kristal yapısındaki değişimler şiddet azalması olarak spektruma yansımıştır.

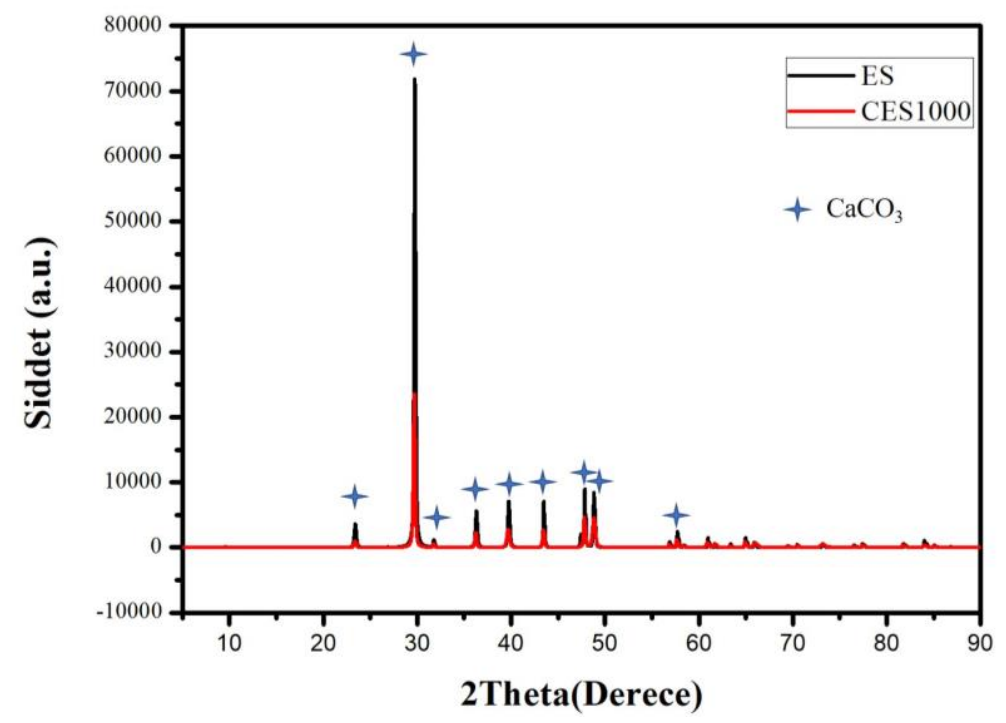

Şekil 5. Kalsine edilmiş ve edilmemiş yumurta kabuklarının XRD spektrumu

\section{E. SEM Analiz Sonuçları} kullanılmıştır.

SEM analizi polyester/yumurta kabuğu partikül kompozitlerinin morfolojisini incelemek için 

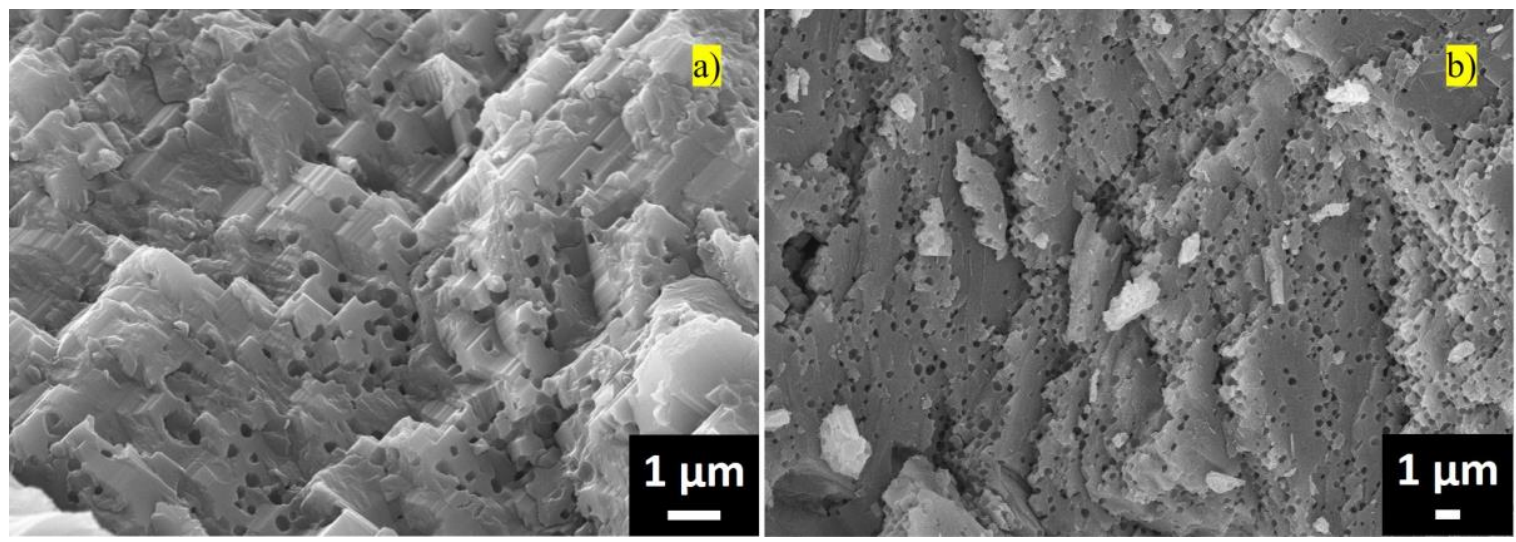

Şekil 6. 12,5 hacim oranında dökülen kompozit malzemelere ait SEM görüntüleri a) $\theta<0,090$ boyutunda, b) $0,090<\theta<0,125$ boyutunda
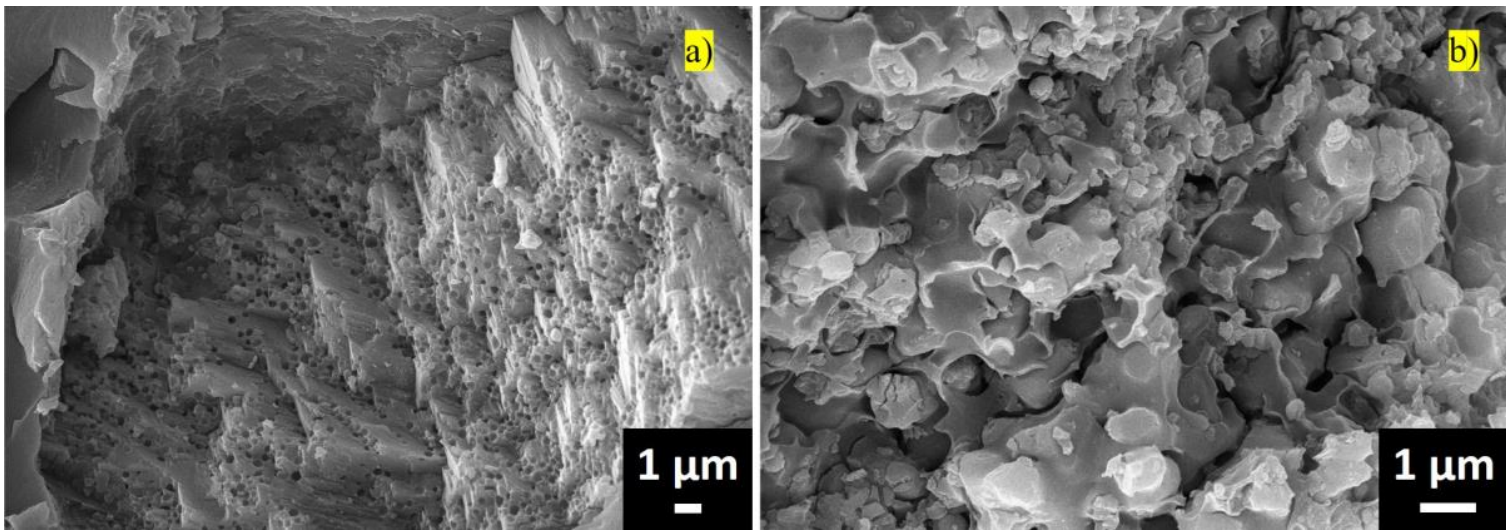

Şekil 7. 12,5 hacim oranında dökülen kompozit malzemelere ait SEM görüntüleri a) $0,125<\theta<0,250$ boyutunda b) CES800
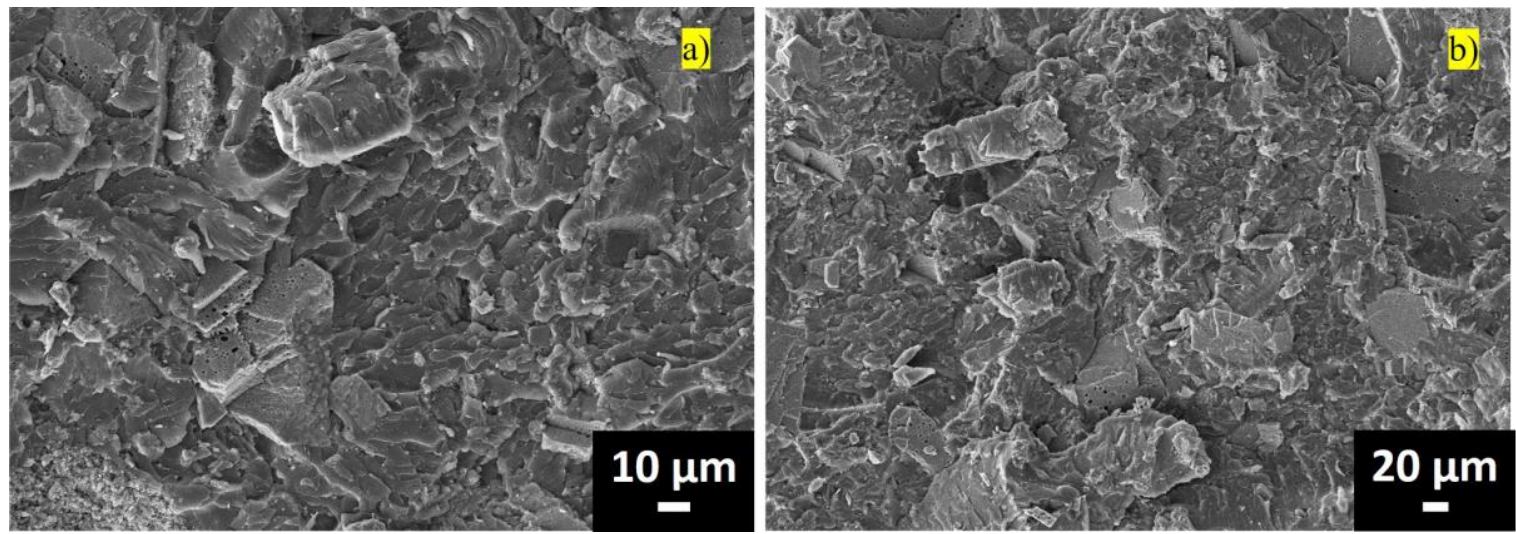

Şekil 8. 12,5 hacim oranında dökülen kompozit malzemelere ait SEM görüntüleri a) CES900 b) CES1000

Şekil 6-8'de SEM görüntüleri incelendiğinde yumurta kabuğu parçacığının mikro yapısı, parçacıkların boyutunun ve şeklinin değiştiğini ortaya koymaktadır; bununla birlikte, gözenekli düzensiz şekil parçacıklarından oluşmaktadırlar. Morfolojik çalışma, yumuşak küresel yüzeye sahip bir takviye olarak yumurta kabuğunun, etkileşim için daha fazla yüzey alanına sahip olduğunu göstermiştir. Polimer matriksinde yumurta kabuğu partiküllerinin iyi bir dağılıma sahip olduğu gözlenmektedir. Mikrograflar, yumurta kabuğu parçacıklarının polyester reçinesi ile homojen bir şekilde karıştırıldığını açıkça göstermektedir. Parçacıklar matris ara yüzü kompozit özelliklerde önemli bir rol oynar. Kompozitlerin yüksek mekanik özellikleri için güçlü partikül-matris ara yüz bağı önemlidir [6]. En küçük parçacık boyutuna sahip yumurta kabuğu ile hazırlanan kompozitin ara yüzey bağlantısının diğer parçacık boyutlarına göre daha iyi olduğu mikro yapılardan anlaşılmaktadır. En iyi mekanik dayanım en küçük parçacık boyutu ile hazırlanan kompozitte görüldüğü için bu durum kompozitlerin mekanik özellik sonuçları ile de paralellik göstermektedir. Kalsinasyon sıcaklığı arttıkça 
kristallik derecesi artarak yumurta kabuğu ile polimer matriksinin ara yüzey bağlanması ve etkileşimi artmıştır [14]. $1000{ }^{\circ} \mathrm{C}^{\prime}$ de kalsine edilen yumurta kabukları ile elde edilen SEM görüntülerinde polimer ve yumurta kabuğunun etkileşimleri daha belirginken daha düşük sıcaklıklardaki SEM görüntüleri incelendiğinde yumurta kabuğunun karakteristik yapısı ön plandadır ve etkileşim daha azdır (Şekil 7b).

\section{SONUÇLAR}

Bu çalışmada yumurta kabuğu tozu takviyeli polyester kompozit malzeme üretimi gerçekleştirilmiştir. Üretilen kompozit malzemelerde dolgu maddesinin artan hacim oranlarıyla eğilme dayanımı, elastik modül, sertlik değerlerinde artış gözlenmiştir. Parçacık boyutunun azalması yumurta kabuğunun polyester ile daha iyi ara yüzey etkileşimi göstererek elde edilen kompozitlerin mekanik dayanımlarının artmasına sebep olmuştur. Parçacık boyutunun düşük olması kompozitin fiziksel özelliklerinde de iyileştirme göstermiştir. Açık gözeneklilikleri ve su emmeleri parçacık boyutu azaldıkça düşüş göstermiştir.

Kalsine sıcaklığının artmasıyla eğilme dayanımı ve elastik modülünde artış sertliğinde ise azalma görülmüştür. Sıcaklık, kompozitlerin fiziksel özelliklerinde kütle yığın yoğunluğunda azalmaya sebep olurken \% açık gözeneklilik, \% su emmelerinde ve \% şişme kalınlıklarında artışa sebep olmuştur. Sıcaklığın artmasıyla kristal yapı artarak gözeneklilik artış göstermiştir bu durum kompozitlerin fiziksel özelliklerinde olumsuz etkilere neden olmuştur. Gözenekliliğin artması ile birlikte kompozitlerin su emmesi ve buna bağlı olarak şişme kalınlığı artış göstermiştir. Bu özellik kompozit yapılarında genel olarak istenmeyen bir özellik olup endüstride kullanım alanının kısıtlanmasına neden olmaktadır. Faz analizi sonucunda kalsine edilmiş yumurta kabuğunda reaksiyon sonucunda kütle kaybına bağlı olarak ana ve yardımcı pik şiddetlerinde azalma meydana gelmiştir. Yapılan bu çalışma ile yumurta kabuğu katkısının polimer kompozit malzemelerin mekanik ve bazı fiziksel özelliklerini olumlu yönde iyileştirdiği ortaya konmuştur.

\section{KAYNAKLAR}

[1] Igwe, I.O., Onuegbu, G.C. (2012). Studies on Properties of Eggshell and Fish Bone Powder Filled Polypropylene. Amerikan Journal of Polymer Science, 2(4), 56-61.

[2] Durmuşoğlu, İ. (2005). Kompozit Döşeme ve Kirişlerin Hesabı ve Kompozit Kirişlerin Stabilite Problemleri. Yüksek Lisans Tezi, Yıldız Teknik Üniversitesi, Fen Bilimleri Enstitüsü, İnşaat Mühendisliği Anabilim Dalı, İstanbul.

[3] Kuru, D., Akpinar Borazan, A., Guru, M. (2018). Effect of chicken feather and boron compounds as filler on mechanical and flame retardancy properties of polymer composite materials. Waste Management\&Research, 36(11), 1029-1036.

[4] Toro, P., Quijada, R., Yazdani-Pedram, M., Arias, J.L. (2007). Eggshell, a new bio-filler for polypropylene composite. Materials Letters, 61(22), 4347-4350.

[5] Shuhadah, S., Supri, A.G. (2009). LDPE-Isophthalic Acid-Modified Eggshell Powder Composites. Journal of Physical Science, 20(1), 87-98.

[6] Hassan, B., Vera, V.-A., Patrick,S. (2012). Development of Polyester/Eggshell Particulate Composites. Tribology in Industry, 34(4), 217-225.

[7] Bootklad, M., Kaewtatip,K. (2013). Biodegradation of Thermoplastic Starch/Eggshell Powder Composites. Carbohydrate Polymers, 2(97), 315-320.

[8] Nwanonenyi, S.C., Chike-Onyegbula, C.O. (2013). Water Absorption, Flammability and Mechanical Properties of Linear Low Density Polyethylene/Eggshell Composite. Savap International, 4(1), 352-358.

[9] Ramesh, C., Krishna, M.V., Bezawada, S. (2014). Evaluation of Mechanical Properties of PolyamideEggshell Powder Composite Materials. The International Journal of Science \& Technoledge, 2321(919), 90-95.

[10] Senthil, J., Raj, M. (2015). Preparation and Characterization of Reinforced Eggshell Polymer Composites. International Journal on Mechanical Engineering and Robotics, 3(3), 7-17.

[11] Katırcıŏglu-Bayel, D. (2018). Fire Retardant Mineral Fillers. Omer Halisdemir University Journal of Engineering Sciences, 7(3), 1175-1179. 
[12] Zaman, T., Mostari, M.S., Mahmood, M.A.A., Rahman, M.S. (2018). Evolution and characterization of eggshell as a potential candidate of raw material. Ceramica, 64(370), 236-241.

[13] Ghabeer, T., Dweiri, R., Al-Khateeb, S. (2012). Thermal and Mechanical Characterization of Polypropylene/eggshell biocomposites. Journal of Reinforced Plastics and Composites, 32(6), 402-409.

[14] Villarreal-Lucio, D.S., Rivera-Armenta, J.L., Martínez-Hernández, A.L., Estrada-Moreno, I.A. (2018). Effect of Eggshell Particle Size in Thermal and Thermomechanical Properties of Pp/Eggshell Composites. International Journal Of Engineering Sciences \& Research Technology, 7(4), 82-88.

[15] Turan, Ç. (2010). Akarca Köyü (HATAY) Kireçtaşlarının Hammadde Özelliklerinin Belirlenmesinin ve Kalsinasyon Davranışlarının İncelenmesi. Yüksek Lisans Tezi, Çukurova Üniversitesi, Fen Bilimleri Enstitüsü, Maden Mühendisliği Anabilim Dalı, Adana. 